\title{
THE VALUE OF MULTIDETECTOR COMPUTED TOMOGRAPHY OF ORBITS IN GLOBE PROTRUSION IN COMPARISON TO HERTEL EXOPHTHALMOMETRY
}

\author{
Igor Đorić ${ }^{2}$ Miloš Žarković1,4, Zoran Radojičićc ${ }^{6}$ Nikola Repac ${ }^{3}$, Aleksandar Janićijević ${ }^{3}$, \\ Krešimir Rotim ${ }^{5}$, Goran Tasić1,3 and Lukas Rasulić1,3
}

\begin{abstract}
${ }^{1}$ School of Medicine, University of Belgrade; ${ }^{2}$ Department of Radiology and Magnetic Resonance Imaging, ${ }^{3}$ Clinical Department of Neurosurgery, ${ }^{4} \mathrm{Clinical}$ Department of Endocrinology, Diabetes and Metabolic

Diseases, Clinical Center of Serbia, Belgrade, Serbia; ${ }^{5}$ Clinical Department of Neurosurgery, Sestre milosrdnice University Hospital Center, and University of Applied Health Sciences, Zagreb, Croatia;

${ }^{6}$ Institute for Statistics, Faculty of Organizational Sciences, University of Belgrade, Belgrade, Serbia
\end{abstract}

\begin{abstract}
SUMMARY - The use of multidetector computed tomography (MDCT) is an integral part of contemporary diagnostics of Graves" orbitopathy. The aim of this study was to assess proptosis measurement by MDCT and to compare it to the current standard, Hertel exophthalmometry. A crosssectional study was conducted at the Clinical Centre of Serbia and included 91 patients (19 male and 72 female) with verified Graves' orbitopathy. Globe protrusion measured by MDCT (globe protrusion, GPR) was correlated to Hertel measured protrusion (HR). There was no constant or any systematic bias between the two methods. GPR significantly correlated with the best-corrected visual acuity, while HR did not. Age, body mass index and duration of the disease did not influence proptosis measurement by either method. Proptosis was significantly larger in males. According to our results, GPR compared to HR provides better assessment of the protrusion in Graves' disease. GPR measurement is simple and should always be part of the radiological assessment of orbits in Graves' disease.
\end{abstract}

Key words: Graves ophthalmopathy - diagnostic imaging; Orbit - diagnostic imaging; Multidetector computed tomography; Exophthalmos - diagnosis; Cross-sectional studies

\section{Introduction}

Hyperthyroidism is commonly associated with thyroid associated ophthalmopathy, however, in $5 \%$ to $10 \%$ of cases it is euthyroid. Graves' disease is an autoimmune disease, affecting the thyroid, orbital and periorbital tissue functionality ${ }^{1}$. Clinically, it is present in around $50 \%$ of Graves' disease patients ${ }^{2}$. In the Olmsted district, Minnesota, the incidence of Graves' orbitopathy is 16/100,000 in females and 2.9/100,000 in males ${ }^{3}$. Most of the patients are in the age range of

Correspondence to: Prof. Lukas Rasulić, $M D, P b D$, School of Medicine, University of Belgrade, Clinical Department of Neurosurgery, Clinical Center of Serbia, Višegradska 26, 11000 Belgrade, Serbia

E-mail: Lukas.rasulic@gmail.com, Lukas.rasulic@ksc.ac.rs

Received March 15, 2016, accepted March 20, 2017
30 to 50 years $^{4}$. Smoking is the most serious risk factor for the development of Graves' orbitopathy ${ }^{5}$.

The hallmark manifestation of Graves' orbitopathy is proptosis. Hertel exophthalmometry usually quantifies proptosis. However, the design of an exophthalmometer affects its accuracy ${ }^{6-8}$. Therefore, the aim of this study was to assess proptosis measurement by multidetector computed tomography (MDCT) and compare it to Hertel exophthalmometry as the current standard.

\section{Materials and Methods}

This cross-sectional study was conducted from September 2008 to October 2013 at Department of Radiology and Magnetic Resonance, Clinical Depar- 
ment of Endocrinology, Diabetes and Metabolic Diseases, and Clinical Department of Ophthalmology, Clinical Center of Serbia. The Institutional Review Board of the Clinical Center of Serbia approved the study.

The study included 182 orbits of 91 patients (19 male and 72 female) with confirmed Graves' orbitopathy. Twelve patients were not included in the study due to incomplete data.

The following demographic, anthropometric and clinical parameters were collected: age and gender, number of cigarettes and smoking habit over years, body weight, body height, body mass index (BMI), duration of thyroid function disorder, and duration of ocular signs.

The following ophthalmology parameters were analyzed: proptosis degree measured with Oculus Hertel exophthalmometer, ocular pressure, best-corrected visual acuity (BCVA), presence of lagophthalmos, and preservation of color vision. Strabismus was classified according to Gorman diplopia scoring 9 .

Patients were also categorized according to the severity ${ }^{10}$, and clinical activity score (CAS).

Multidetector computed tomography of orbits was done using a GE Healthcare LightSpeed VCT 64-slice CT scanner or GE Healthcare BrightSpeed Elite 16-slice CT scanner, according to standardized protocols for orbits in adults. All MDCT examinations were done using intravenous application of iodide contrast (Ultravist $300 \mathrm{mg} / \mathrm{mL}$ ) $50 \mathrm{~mL}$, with 40-s delay.

The following parameters acquired by MDCT were analyzed: diameters of extraocular muscles (muscle width and thickness), unilateral or bilateral affection of extraocular muscles (in relation to muscle width and thickness), length of interzygomatic line, distance between interzygomatic line, bulbar front polarity (globe protrusion, GPR) and volume of retrobulbar space.

Muscle width and thickness were measured for individual muscles (inferior rectus, medial rectus, lateral rectus, superior rectus and superior obliquus). Protrusion degree was measured with shortest (perpendicular) distance from interzygomatic line up to sclera surface for each bulb individually, and was expressed in $\mathrm{mm}$, abbreviated defined as GPR value (Fig. 1).

The volume of retrobulbar space was calculated by software using 'contouring' method for the right and left orbit separately ${ }^{11}$ (Fig. 1).

\section{Data analysis}

Data analysis was performed using the method of descriptive analysis and exploratory analysis. Student's t-test was used to compare two independent groups, and Pearson $\chi^{2}$-test was used to compare categorical parameters. Pearson correlation coefficient and coefficient of determination were used as a measure of linear

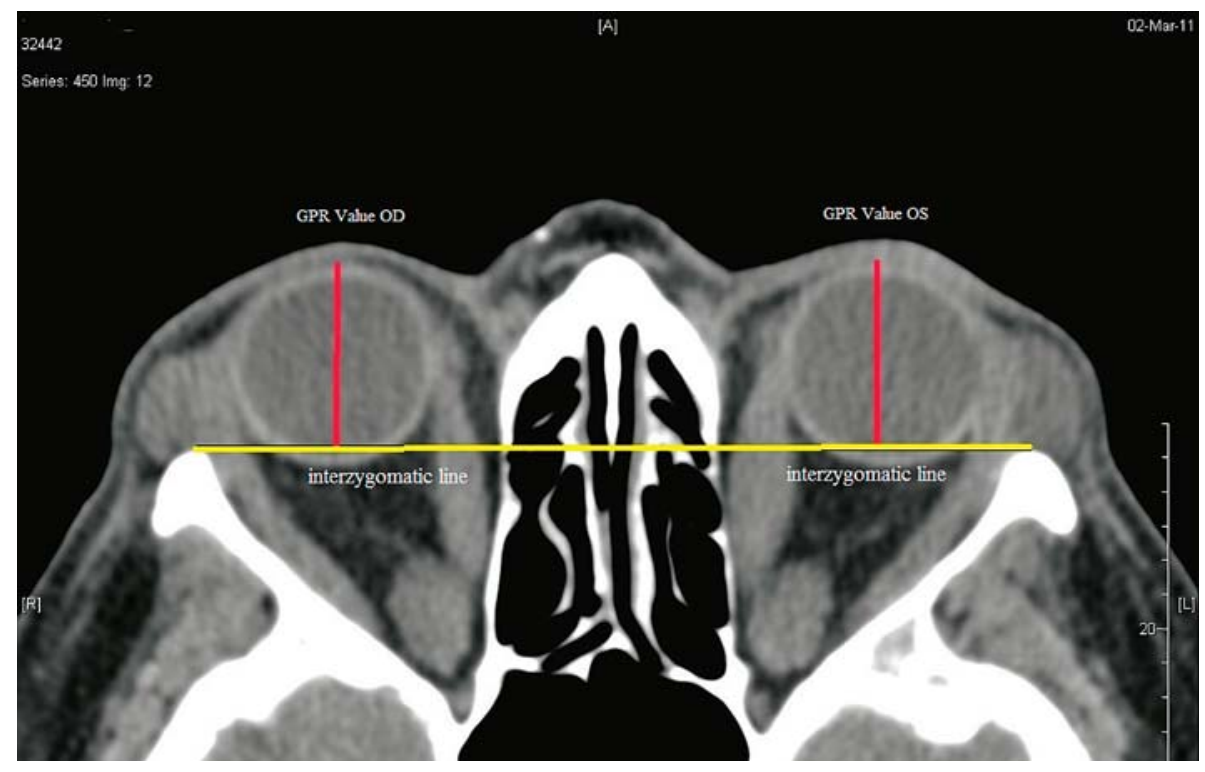

Fig. 1. Schematic display of interzygomatic line (marked in yellow) and both globe protrusion (GPR) values (marked in red). 
association. Spearman correlation coefficient was used as a measure of association between scores. To assess constant and systemic bias between the measurement

Table 1. Anthropometric and clinical characteristics of study subjects $(N=91)$

\begin{tabular}{|c|c|c|}
\hline \multicolumn{2}{|l|}{ Patient age (years) } & $49.49 \pm 12.02$ \\
\hline \multicolumn{2}{|c|}{ Smoking habit (pack-years) } & $26(5-126)$ \\
\hline \multicolumn{2}{|c|}{ Body mass index $\left(\mathrm{kg} / \mathrm{m}^{2}\right)$} & $27.31 \pm 5.07$ \\
\hline \multicolumn{2}{|c|}{ Duration of thyroid disorders (months) } & $30(2-291)$ \\
\hline \multicolumn{2}{|c|}{ Duration of ocular signs (months) } & $15(1-264)$ \\
\hline $\begin{array}{l}\text { Strabismus } \\
\text { (Gorman diplopia } \\
\text { scoring) }\end{array}$ & \begin{tabular}{|l|} 
Constant \\
Inconstant \\
Intermittent \\
None \\
\end{tabular} & $\begin{array}{l}32.97 \% \\
12.09 \% \\
16.48 \% \\
38.46 \% \\
\end{array}$ \\
\hline \multicolumn{2}{|c|}{ Color vision (Yes vs. No) } & \begin{tabular}{|l|}
$94.50 \%$ \\
vs. $5.50 \%$ \\
\end{tabular} \\
\hline $\begin{array}{l}\text { Severity } \\
\text { classification in } \\
\text { Graves' orbitopathy }\end{array}$ & $\begin{array}{l}\text { Sight-threatening } \\
\text { Moderate to severe } \\
\text { Mild }\end{array}$ & $\begin{array}{l}9.90 \% \\
43.40 \% \\
46.70 \%\end{array}$ \\
\hline
\end{tabular}

Data are presented as mean $\pm \mathrm{SD}$, or median, min-max

Table 2. Mean values in Graves' orbitopathy subjects

\begin{tabular}{|c|c|c|c|}
\hline \multicolumn{2}{|l|}{ Parameter } & \multirow{2}{*}{$\begin{array}{l}\text { OD } \\
21.57 \pm 3.91\end{array}$} & \multirow{2}{*}{\begin{tabular}{|l} 
OS \\
$21.21 \pm 4.24$
\end{tabular}} \\
\hline \multirow{4}{*}{$\begin{array}{l}\text { GPR value } \\
(\mathrm{mm})\end{array}$} & All & & \\
\hline & Male & $23.34 \pm 3.61$ & $23.30 \pm 4.19$ \\
\hline & Female & $21.11 \pm 3.87$ & $20.65 \pm 4.11$ \\
\hline & $\mathrm{p}$ & 0.025 & 0.015 \\
\hline \multirow{4}{*}{$\begin{array}{l}\text { Hertel value } \\
(\mathrm{mm})\end{array}$} & All & $21.78 \pm 3.58$ & $21.33 \pm 3.60$ \\
\hline & Male & $23.16 \pm 3.61$ & $23.10 \pm 3.75$ \\
\hline & Female & $21.42 \pm 3.51$ & $20.86 \pm 3.43$ \\
\hline & $\mathrm{p}$ & 0.060 & 0.015 \\
\hline \multicolumn{2}{|c|}{$\begin{array}{l}\text { Thickness of extraocular } \\
\text { muscles }(\mathrm{mm})\end{array}$} & $4.98 \pm 1.17$ & $4.86 \pm 1.30$ \\
\hline \multicolumn{2}{|c|}{$\begin{array}{l}\text { Width of extraocular } \\
\text { muscles (mm) }\end{array}$} & $9.87 \pm 1.24$ & $9.69 \pm 1.28$ \\
\hline \multicolumn{2}{|c|}{$\begin{array}{l}\text { Volume of retrobulbar } \\
\text { space }(\mathrm{mm})\end{array}$} & $25.60 \pm 4.79$ & $25.65 \pm 4.88$ \\
\hline \multicolumn{2}{|l|}{ BCVA } & $0.95 \pm 0.10$ & $0.93 \pm 0.12$ \\
\hline \multicolumn{2}{|c|}{ BCVA $(1.0$ vs. <1.0) } & $\begin{array}{l}76.9 \% \\
\text { vs. } 23.1 \%\end{array}$ & $\begin{array}{l}70.3 \% \\
\text { vs. } 29.7 \%\end{array}$ \\
\hline \multicolumn{2}{|c|}{ Ocular pressure $(\mathrm{mm} \mathrm{Hg})$} & $16.93 \pm 2.94$ & $16.91 \pm 3.18$ \\
\hline \multicolumn{2}{|c|}{$\begin{array}{l}\text { Lagophthalmos } \\
\text { (Yes vs. No) }\end{array}$} & $\begin{array}{l}24.20 \% \text { vs. } \\
75.80 \%\end{array}$ & $\begin{array}{l}25.30 \% \text { vs. } \\
74.70 \%\end{array}$ \\
\hline
\end{tabular}

$\mathrm{OD}=$ right eye; $\mathrm{OS}$ = left eye; $\mathrm{GPR}$ = globe protrusion; $\mathrm{BCVA}=$ best-corrected visual acuity methods, Bland-Altman Plot was used. Significance was accepted at $p<0.05$. Data are presented as mean $\pm \mathrm{SD}$, or median and range. Data analysis was done with the SPSS v. 20.0 statistical software.

\section{Results}

Demographic, ophthalmology and MDCT measurements are shown in Tables 1, 2 and 3. Fifty-three (58.24\%) patients were examined on the GE Healthcare LightSpeed VCT 64-slice CT scanner and 38 (41.76\%) patients on the GE Healthcare BrightSpeed Elite 16-slice CT scanner. CT scanner characteristics are listed in Table 4.

Initial Clinical Activity Score (CAS) ranged from zero to six, while the mean value was $1.78 \pm 1.34$ for the right eye $(\mathrm{OD})$ and $1.63 \pm 1.45$ for the left eye $(\mathrm{OS})$.

The MDCT and Hertel exophthalmometer measurements are presented in Table 2 . There was signifi-

Table 3. Gorman diplopia scoring and muscle thickness and width on both eyes

\begin{tabular}{|c|c|c|c|c|}
\hline Parameter & $\begin{array}{l}\text { Gorman diplopia } \\
\text { scoring }\end{array}$ & Mean & SD & p \\
\hline \multirow{5}{*}{$\begin{array}{l}\text { Thickness of } \\
\text { EOM (OD) }\end{array}$} & None & 4.64 & 1.12 & \multirow{5}{*}{0.004} \\
\hline & Intermittent & 4.49 & 1.11 & \\
\hline & Inconstant & 5.73 & 0.71 & \\
\hline & Constant & 5.34 & 1.18 & \\
\hline & Total & 4.98 & 1.17 & \\
\hline \multirow{5}{*}{$\begin{array}{l}\text { Thickness of } \\
\text { EOM (OS) }\end{array}$} & None & 4.49 & 1.29 & \multirow{5}{*}{0.002} \\
\hline & Intermittent & 4.24 & 1.13 & \\
\hline & Inconstant & 5.19 & 0.96 & \\
\hline & Constant & 5.49 & 1.23 & \\
\hline & Total & 4.86 & 1.29 & \\
\hline \multirow{5}{*}{$\begin{array}{l}\text { Width of } \\
\text { EOM (OD) }\end{array}$} & None & 9.58 & 1.09 & \multirow{5}{*}{0.005} \\
\hline & Intermittent & 9.23 & 1.16 & \\
\hline & Inconstant & 10.24 & 0.97 & \\
\hline & Constant & 10.40 & 1.33 & \\
\hline & Total & 9.87 & 1.24 & \\
\hline \multirow{5}{*}{$\begin{array}{l}\text { Width of } \\
\text { EOM (OS) }\end{array}$} & None & 9.37 & 1.28 & \multirow{5}{*}{0.002} \\
\hline & Intermittent & 9.12 & 0.86 & \\
\hline & Inconstant & 9.65 & 1.00 & \\
\hline & Constant & 10.38 & 1.29 & \\
\hline & Total & 9.69 & 1.28 & \\
\hline
\end{tabular}

$\mathrm{EOM}=$ extraocular muscles; $\mathrm{OD}=$ right eye $\mathrm{OS}$ = left eye 
Table 4. Multidetector computed tomography technical specifications

\begin{tabular}{|l|l|l|}
\hline \multirow{2}{*}{ Parameter } & \multicolumn{2}{|l|}{ Scanner } \\
\cline { 2 - 3 } & $\begin{array}{l}\text { GE } \\
\text { BrightSpeed } \\
\text { Elite 16 }\end{array}$ & $\begin{array}{l}\text { GE } \\
\text { LightSpeed } \\
\text { VCT 64 }\end{array}$ \\
\hline Scan type & Helical & Helical \\
Rotation time (sec) & 0.6 & 0.5 \\
Beam collimation (mm) & 10 & 20 \\
Detector rows & 16 & 16 \\
Pitch & 0.562 & 0.531 \\
Speed (mm/rot) & 5.625 & 10.62 \\
Detector configuration & $16 x 0.625$ & $64 x 0.625$ \\
Slice thickness (mm) & 1.25 & 1.25 \\
Interval (mm) & 0.75 & 0.625 \\
Scan FOV & Head & Head \\
kV Interval & $80-140$ & $80-140$ \\
Smart mA/Auto mA & $130-440$ & $200-450$ \\
range & & \\
Manual mA & 350 & 400 \\
Noise index & 5.6 & 5.6 \\
DFOV (cm) & $18-20$ & $18-22$ \\
Contrast bolus (mL) & 50 & 50 \\
Flow of contrast (mL/s) & 4 & 4 \\
Delayed time (s) & 40 & 40 \\
\hline
\end{tabular}

cant correlation between globe protrusion measurements by MDCT and HR (HR vs. GPR for OD $\mathrm{r}=0.760 ; \mathrm{p}=0.000 ; \mathrm{HR}$ vs. GPR for OS $\mathrm{r}=0.799$; $\mathrm{p}=0.000$ ). Concordance between CT and HR measurements was good with no constant or any systematic bias (bias mm with 95\%CI OD-OS; see Figures 2 and 3 ).

Significant correlation was found between the BCVA and globe protrusion measured with MDCT, but not with globe protrusion measured with $\mathrm{HR}$ (HR and BCVA $r=-0.166 ; p=0.116$ for OD and $r=-0.095$; $\mathrm{p}=0.369$ for OS; GPR and BCVA (OD: $r=-0.208$; $\mathrm{p}=0.048$; OS: $r=-0.340 ; \mathrm{p}=0.001$ ).

Globe protrusion measured by both MDCT and HR correlated significantly with intraocular pressure (OD: HR $r=0.315 ; \mathrm{p}=0.002$; GPR $\mathrm{r}=0.311 ; \mathrm{p}=0.003$; OS: HR r=0.271; $\mathrm{p}=0.009$; GPR $\mathrm{r}=0.311 ; \mathrm{p}=0.003$ ). However, there was no correlation between intraocular pressure and BCVA (OD: $r=-0.142 ; \mathrm{p}=0.170$; OS: $\mathrm{r}=-$ $0.130 ; \mathrm{p}=0.220$ ).
Retro-orbital muscle thickness and total retro-orbital volume correlated significantly with globe protrusion measured either by $\mathrm{CT}(\mathrm{OD}: \mathrm{r}=0.634 ; \mathrm{p}=0.000$; OS: $r=0.676 ; p=0.000)$ or HR (OD: $r=0.469 ; p=0.000$; OS: $r=0.514 ; p=0.000$ ).

We found no influence of age and obesity expressed as BMI on globe protrusion measured with MDCT or HR. However, there was a significant difference in globe protrusion between males and females (Table 2).

Duration of thyroid function disorder and duration of ocular signs showed no significant correlation with GPR (OD: $r=0.031 ; p=0.770$; OS: $r=-0.059 ; p=0.581$ ) and HR value (OD: $r=0.117 ; p=0.271$; OS: $r=0.030$; $\mathrm{p}=0.776$ ), and so did duration of ocular signs with GPR (OD: $r=0.069 ; \mathrm{p}=0.514$; OS: $r=0.013$; $\mathrm{p}=0.904$ ) and HR value (OD: $r=0.068$; $\mathrm{p}=0.523$; OS: $\mathrm{r}=0.037$; $\mathrm{p}=0.726)$.

The CAS score correlated significantly with both GPR and HR (OD: GPR: $r=0.272 ; \mathrm{p}=0.009$; OS: GPR: $r=0.412 ; p=0.000$, OD: HR: $r=0.304 ; p=0.003$; OS: HR: $r=0.381 ; \mathrm{p}=0.000)$. Patients with lost color vision had higher GPR and HR values (GPR OD: $26.14 \pm 3.85$ vs. $21.31 \pm 3.77$; $\mathrm{p}=0.007$; GPR OS: $27.30 \pm$ 4.36 vs. 20.86 $\pm 3.99 ; \mathrm{p}=0.001$; HR OD: $23.60 \pm 4.39$ vs. $21.68 \pm 3.53 ; p=0.246$; HR OS: $24.60 \pm 4.39$ vs. $21.14 \pm$ 3.49; $\mathrm{p}=0.036$ ). Patients with lagophthalmos had higher GPR and HR values compared to those without it (GPR OD: $\mathrm{p}=0.010$; HR OD: $\mathrm{p}=0.001$; GPR OS: $p=0.050$; HR OS: $p=0.005$ ).

The Gorman strabismus score ${ }^{9}$ was not associated with changes in GPR (OD: $r=0.145 ; p=0.169$; OS: $r=0.192 ; p=0.069$ ) and HR values (OD: $r=-0.009$; $\mathrm{p}=0.932$; OS: $\mathrm{r}=0.054 ; \mathrm{p}=0.612$ ). However, this score was associated with increased muscle thickness and width on both eyes $(\mathrm{p}<0.010)$ (Table 3$)$.

\section{Discussion}

Multidetector computed tomography of orbits allows high-speed volumetric acquisition and multiplanar reconstruction $(\mathrm{MPR})^{12}$. Axial and coronal MDCT scanning of the orbits is a simple, fast and noninvasive method, which provides a wide spectrum of information about extraocular muscles and retrobulbar space in general ${ }^{13}$.

The aim of this study was to assess proptosis measurement by MDCT and to compare it with Hertel exophthalmometry as the current standard. We found 


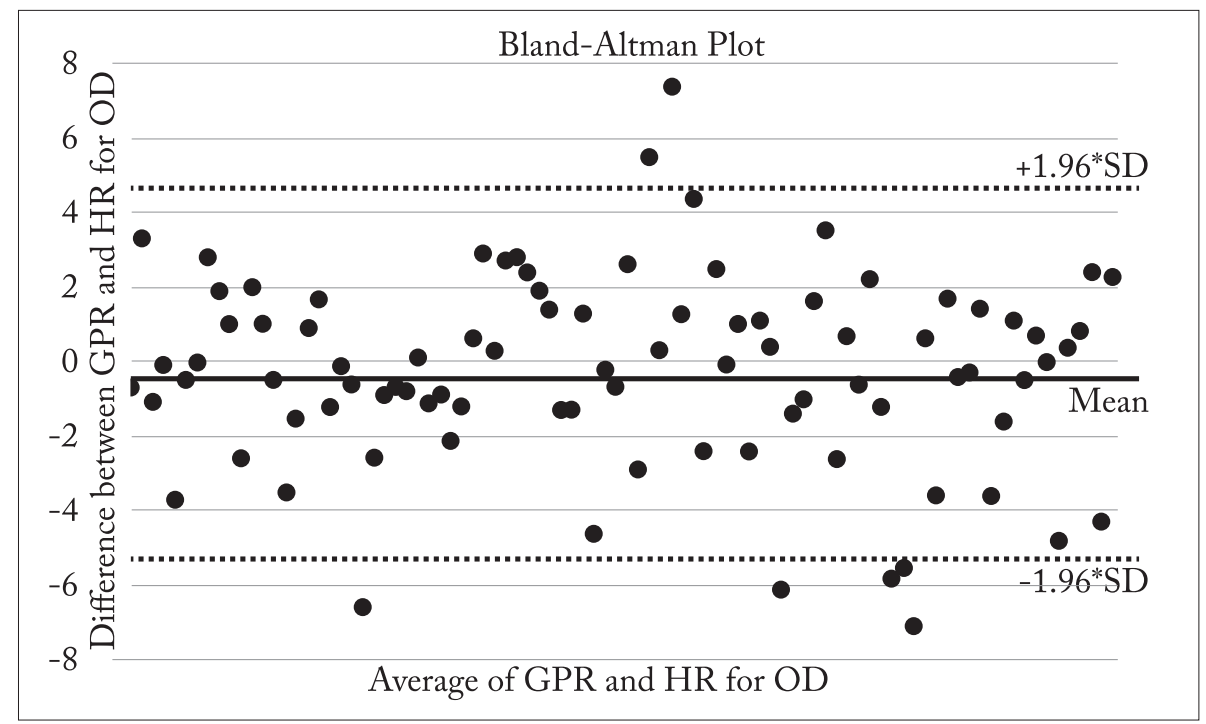

Fig. 2. Bland-Altman Plot between globe protrusion (GPR) and Hertel measured

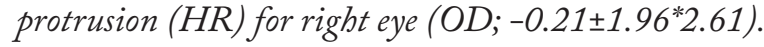

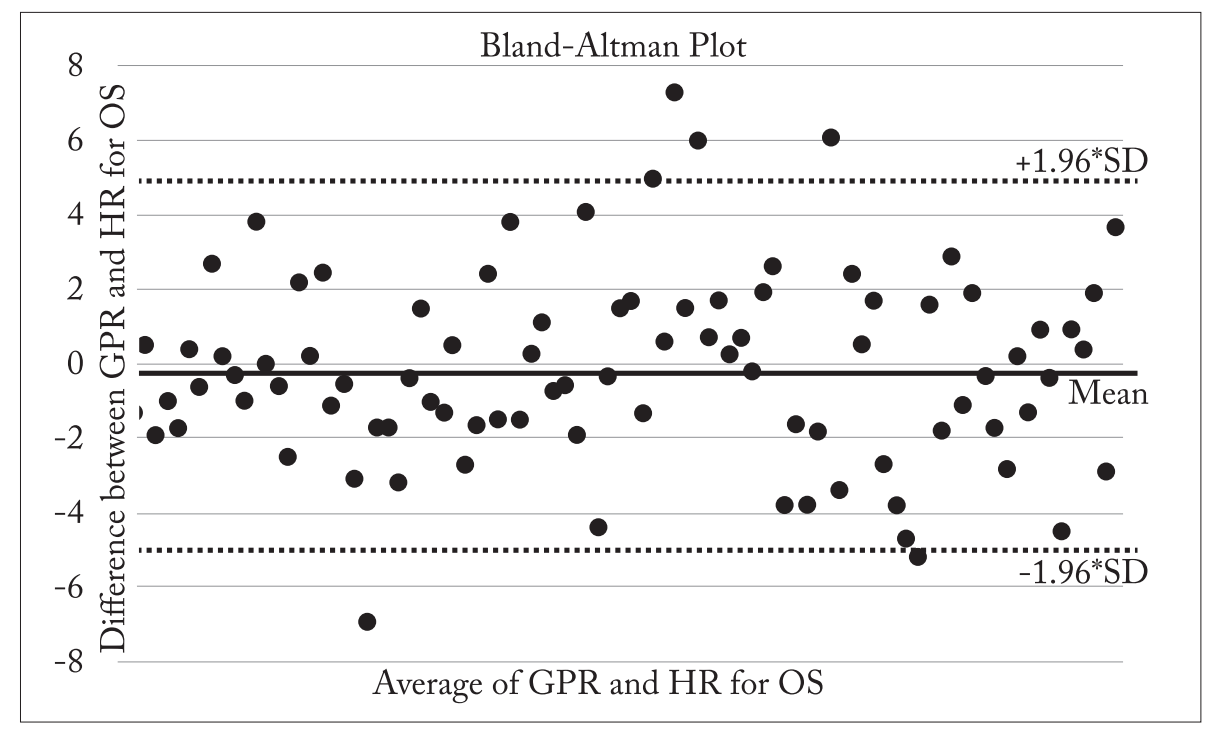

Fig. 3. Bland-Altman Plot between globe protrusion (GPR) and Hertel measured

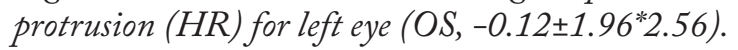

excellent correlation between these two methods, with almost no constant bias and no systematic bias at all. However, only MDCT measurement correlated with BCVA, while both methods correlated with intraocular pressure and CAS score. Also, a subject with loss of color vision or lagophthalmos had higher proptosis values by both methods. Gorman strabismus score was not associated with changes in GPR and HR values, but was associated with an increased retro-orbital muscle thickness and width. Retro-orbital muscle thickness and total retro-orbital volume significantly correlated with globe protrusion measured by either CT or HR.

Based on all data, we conclude that GPR and HR measure the same process (exophthalmos) caused by increase in the retro-orbital volume. Both measuring techniques are associated with other parameters of the disease severity. However, there is a distinct advantage 
of MDCT as it is the only method that significantly correlates with BCVA, while also showing higher correlation with other parameters of disease severity. Besides, the type of exophthalmometer, patient and examiner factors influence measurement when using Hertel method. Vardizer et al. ${ }^{7}$ assessed the accuracy of eight different exophthalmometers and showed the design of exophthalmometers to influence their accuracy. They also found that measurement was influenced by patient head position changing during examination, gaze direction, difference in the device to orbital border. Also, Van den Bosch ${ }^{14}$ showed that non-moving of the examiner during examination can result in measurement errors.

In our study, neither duration of thyroid dysfunction nor duration of ocular disease influenced proptosis measured by MDCT or HR.

We found that neither age nor obesity had any influence on globe protrusion measurements by MDCT or HR. However, males had a significantly larger globe protrusion as compared to females. In this study, only subjects with Graves' disease were included, so it was not possible to differentiate whether it was real sexual dimorphism or a disease-induced one.

Beden et al. ${ }^{15}$ measured proptosis using Hertel exophthalmometer in 2477 Turkish subjects. The mean HR proptosis was $13 \mathrm{~mm}$, with upper 95\%CI of 17 $\mathrm{mm}$. They also found that HR proptosis was significantly reduced after the age of 30 . We could not replicate this finding, probably due to different study populations, but it should be taken into account that our sample was much smaller.

Nishida et al $^{16}$ suggested that enlargement of retrobulbar lipid volumes was more significant for ocular protrusion than retro-ocular muscle thickening. However, Fang et al. ${ }^{13}$ found that both retrobulbar lipid volume and retro-ocular muscle thickening were predictors of globe protrusion, severity of the disease and prognosis of the disease. Our study confirmed the findings by Fang et al. We found that Gorman diplopia score was not associated with proptosis level, but it correlated with muscle involvement on MDCT scan, a finding similar to a recent one reported by Laurberg et al. ${ }^{17}$.

\section{Conclusion}

According to our results, GPR compared to HR provides better assessment of protrusion in Graves' disease. GPR measurement is simple and should always be part of radiological assessment of orbits in Graves' disease.

\section{References}

1. Mallika PS, Tan AK, Aziz S, Syed Alwi SAR, Chong MS, Vanitha R, Intan G. Thyroid associated ophthalmopathy - a review. Malays Fam Physician. 2009;4:8-14. PMCID: PMC 4170380

2. Wiersinga WM, Bartalena L. Epidemiology and prevention of Graves' ophthalmopathy. Thyroid. 2002;12:855-60. http:// dx.doi.org/10.1089/105072502761016476

3. Lazarus JH. Epidemiology of Graves'orbitopathy (GO) and relationship with thyroid disease. Best Pract Res Clin Endocrinol Metab. 2012;26:273-9. http://dx.doi.org/10.1016/j.beem. 2011.10.005

4. Bodh SA, Kamal S, Goel R, Kumar S, Bansal S, Singh M. Thyroid associated ophthalmopathy. DJO. (serial online) 2012; 22:249-55. Available from: http://www.djo.org.in/articles/ 22/4/thyroid-associated.htm

5. Bartalena L. Smoking and Graves' disease. J Endocrinol Invest. 2002;25:152-7. http://dx.doi.org/10.1007/BF03344027

6. Dickinson J, Perros P. Controversies in the clinical evaluation of active thyroid-associated orbitopathy: use of a detailed protocol with comparative photographs for objective assessment. Clin Endocrinol. 2001;55:283-303. PMID:11589671

7. Vardizer Y, Berendschot TT, Mourits MP. Effect of exophthalmometer design on its accuracy. Ophthal Plast Reconstr Surg. 2005;21:427-30. http://dx.doi.org/10.1097/01.iop.0000 180066.87572 .39

8. Sleep TJ, Manners RM. Interinstrument variability in Herteltype exophthalmometers. Ophthal Plast Reconstr Surg. 2002;18: 254-7.http://dx.doi.org/10.1097/01.IOP.0000021971.72318.95

9. Bahn RS, Gorman CA. Choice of therapy and criteria for assessing treatment outcome in thyroid-associated ophthalmopathy. Endocrinol Metab Clin. 1987;16:391-407. PMID: 3319588

10. Bartalena L, Baldeschi L, Dickinson A, Eckstein A, KendallTaylor P, Marcocci C, Mourits M, Perros P, Boboridis K, Boschi A, Curro N, Daumerie C, Kahaly GJ, Krassas GE, Lane CM, Lazarus JH, Marino M, Nardi M, Neoh C, Orgiazzi J, Pearce S, Pinchera A, Pitz S, Salvi M, Sivelli P, Stahl M, von Arx G, Wiersinga WM. Consensus statement of the European Group on Graves' orbitopathy (EUGOGO) on management of GO. Eur J Endocrinol. 2008;158:273-85. http://dx.doi. org/10.1530/EJE-07-0666

11. Colli V, Strocchi S, Vite C, Cacciatori M, Rizzi E, Marzoli L, Conte L. Dosimetric and image quality comparison of different 64-slice CT scanners. In: World Congress on Medical Physics and Biomedical Engineering, September 7-12, 2009, Munich, Germany, pp.197-200, http://dx.doi.org/10.1007/978-3-64203879-2_56 
12. Hande PC, Talwar I. Multimodality imaging of the orbit. Indian J Radiol Imaging. [serial online] 2012 [cited 2017 Mar 24]; 22:227-39. Available from: http://www.ijri.org/text.asp? 2012/22/3/227/107184

13. Fang ZJ, Zhang JY, He WM. CT features of exophthalmos in Chinese subjects with thyroid-associated ophthalmopathy. Int J Ophthalmol. 2013;6(2):146-9. http://dx.doi.org/10.3980/j. issn.2222-3959.2013.02.07

14. Van den Bosch WA. Normal exophthalmometry values: the need for calibrated exophthalmometers. Orbit. 2004;23(3): 147-51. http://dx.doi.org/10.1080/01676830490504043

15. Beden Ü, Özarslan Y, Öztürk HE, Sönmez B, Erkan D, Oge I. Exophthalmometry values of Turkish adult population and the effect of age, sex, refractive status, and Hertel base values on Hertel readings. Eur J Ophthalmol. 2008 Mar-Apr;18(2): 165-71. PMID: 18320506

16. Nishida Y, Tian S, Isberg B, et al. Significance of orbital fatty tissue for exophthalmos in thyroid-associated ophthalmopathy. Graefes Arch Clin Exp Ophthalmol. 2002;240:515-20. http:// dx.doi.org/10.1007/s00417-002-0498-3

17. Laurberg P, Berman D, Pedersen IB, Andersen S, Carlé A. Double vision is a major manifestation in moderate to severe Graves' orbitopathy, but it correlates negatively with inflammatory signs and proptosis. J Clin Endocrinol Metab. 2015; 100(5):2098-105. https://doi.org/10.1210/jc.2014-4557

Sažetak

\title{
VRIJEDNOST MULTIDETEKTORSKE KOMPJUTORIZIRANE TOMOGRAFIJE ORBITA U ODREĐIVANJU STUPNJA PROTRUZIJE BULBUSA U USPOREDBI S HERTELOVOM EGZOFTALMOMETRIJOM
}

\author{
I. Đoric, M. Žarković, Z. Radojičic, N. Repac, A. Janičijević, K. Rotim, G. Tasić i L. Rasulić
}

Korištenje multidetektorske kompjutorizirane tomografije (MDCT) je sastavni dio suvremene dijagnostike Gravesove orbitopatije. Cilj ovoga istraživanja bio je ispitati mjerenje stupnja protruzije bulbusa pomoću MDCT i to usporediti s trenutnim standardom, Hertelovom egzoftalmometrijom. Presječno istraživanje je provedeno na Kliničkom centru Srbije, a uključilo je 91 bolesnika (19 muškaraca i 72 žene) s provjerenom Gravesovom orbitopatijom. Stupanj protruzije bulbusa mjeren pomoću MDCT (globe protrusion, GPR) je povezan s izmjerenim stupnjem protruzije bulbusa prema Hertelu (HR). Nije bilo stalne ili sustavne pristranosti između dviju metoda. GPR je bio značajno povezan s najbolje korigiranom oštrinom vida, a HR nije. Dob, indeks tjelesne mase i trajanje bolesti ne utječu na mjerenje stupnja protruzije bulbusa bilo kojim postupkom. Stupanj protruzije bulbusa bio je značajno veći u muškaraca. Prema našim rezultatima, GPR u odnosu na HR omogućuje bolju procjenu stupnja protruzije bulbusa kod Gravesove orbitopatije. Mjerenje GPR je jednostavno i treba uvijek biti dio radiološke procjene orbite kod Gravesove orbitopatije.

Ključne riječi: Gravesova oftalmopatija - slikovna dijagnostika; Orbita - slikovna dijagnostika; Tomografja, kompjutorizirana, multidetektorska; Egzoftalmus - dijagnostika; Presječne studije 